\title{
Bacterioplankton communities in the Southern Ocean: composition and growth response to various substrate regimes
}

\author{
Meinhard Simon*, Sara Billerbeck, Daniel Kessler, Natascha Selje, \\ Andrea Schlingloff
}

Institute for Chemistry and Biology of the Marine Environment, University of Oldenburg, 26111 Oldenburg, Germany

\begin{abstract}
To examine the adaptation of bacterioplankton communities in the Southern Ocean to various biopolymeric substrates, we carried out experiments at the Polar Front and in the Antarctic Coastal Current (CC) in which samples were enriched with agarose, starch, peptone and extracts of the green alga Scenedesmus acutus and diatoms from the Polar Front. Growth and metabolic activity were assessed based on leucine incorporation and turnover rates of glucose, dissolved free amino acids and protein. In both experiments, growth was highest on peptone and the diatom extract and lowest on agarose. There was a general trend of decreasing proportions of Alphaproteobacteria and increasing proportions of Flavobacteria/Sphingobacteria and Gammaproteobacteria. The growth response and shift to Flavobacteria/Sphingobacteria was more pronounced in the $\mathrm{CC}$ experiment. A cluster analysis of denaturing gradient gel electrophoresis (DGGE) banding patterns showed that bacterial communities in each treatment of both experiments differed and that those in the treatments with peptone and the Scenedesmus and diatom extracts clustered together. Sequencing of excised bands revealed that Gammaproteobacteria comprised members of Pseudoalteromonadaceae, the Colwellia cluster of Alteromonadaceae and 1 other cluster. Alphaproteobacteria comprised only members of the Roseobacter clade and the Bacteroidetes phylum only of Flavobacteria and Cytophagales. The results show that the bacterioplankton communities in the Southern Ocean are able to adapt to various biopolymeric substrates. The most pronounced response to the additions of peptone and the diatom extract rich in protein is in line with previous observations that proteins are preferred bacterial substrates in this oceanic region.
\end{abstract}

KEY WORDS: Bacteria - Fluorescence in situ hybridization - DGGE - Cluster analysis · Biopolymers $\cdot$ Southern Ocean Resale or republication not permitted without written consent of the publisher

\section{INTRODUCTION}

During the last 2 decades, the Southern Ocean has been the focus of many research programs because of its sensitivity to climate effects, such as global warming and the impact of enhanced UV irradiation. This is one reason why biogeochemical processes of plankton communities and the heterotrophic picoplankton have been investigated intensively in this region (Lochte et al. 1997, Ducklow et al. 2001, 2012, Kirchman et al. 2009). The composition of the hetero- trophic picoplankton community, including Bacteria and Archaea, has also been studied in the Southern Ocean and most intensely in the last decade. These studies have revealed that Alpha- and Gammaproteobacteria, Sphingobacteria and Flavobacteria of the Bacteroidetes phylum and in particular distinct subclusters of these groups are the major phylogenetic lineages (Simon et al. 1999, Abell \& Bowman 2005a, West et al. 2008, Manganelli et al. 2009, Straza et al. 2010, Ducklow et al. 2011). These findings corroborate observations in other oceanic 
regions, but relevant subclusters of these major phylogenetic lineages in the Southern Ocean differ from other regions with higher water temperatures and other hydrographic regimes (Selje et al. 2004, Abell \& Bowman 2005a, Giebel et al. 2009, Straza et al. 2010, Ghiglione \& Murray 2012).

Despite a general understanding of the major phylogenetic lineages of the bacterioplankton in the Southern Ocean, little information is available on the substrate preferences and organic matter cycling of distinct phylogenetic lineages. Abell \& Bowman (2005b) reported that subclusters of Flavobacteria were the dominant bacteria colonizing and decomposing diatom derived organic matter in various regions of the Southern Ocean. In a study around the western Antarctic Peninsula using microautoradiography and fluorescence in situ hybridization (MAR-FISH), Straza et al. (2010) found that specific subgroups of Gammaproteobacteria, SAR11 and of Sphingobacteria/Flavobacteria were the major bacterioplankton groups in organic matter consumption. Specific phylotypes of Gammaproteobacteria and Sphingobacteria/Flavobacteria were reported to be particularly responsive to glucose plus ammonium additions in a mesocosm experiment in the same region (Ducklow et al. 2011). To better understand organic matter cycling by bacterioplankton phylogenetic lineages in the Southern Ocean, more studies with various potentially important substrates are needed.

We studied the response of bacterioplankton communities to various substrate additions in 2 regions of the Southern Ocean, the Polar Front (PF) and the Antarctic coastal current (CC), in microcosm experiments. We tested whether biopolymers as single carbon (C) and as combined $\mathrm{C}$ and nitrogen (N) sources would result in different growth responses of the ambient bacterioplankton communities. Therefore, we carried out microcosm experiments in which various substrates, i.e. starch, agarose, peptone and an extract of a green alga and of a natural diatom community from the Polar Front, were added to ambient bacterioplankton communities. The growth response and composition of the bacterioplankton communities were analyzed by FISH and denaturing gradient gel electrophoresis (DGGE) of polymerase chain reaction (PCR) amplified 16S rRNA gene fragments, and the nucleotide sequences of excised bands were determined. The results show that distinct differences existed in the community composition and the growth response of the bacterioplankton to the various substrate additions and between the 2 locations.

\section{MATERIALS AND METHODS}

The present study was conducted in the Atlantic sector of the Southern Ocean during cruise ANT XVI/3 in austral fall 1999 with RV 'Polarstern'. It was embedded in a larger study that investigated the substrate turnover and biomass production of heterotrophic picoplankton in the Southern Ocean (Simon et al. 2004, Simon \& Rosenstock 2007) and the community composition of the bacterioplankton (Giebel et al. 2009). Samples for the microcosm experiments were taken with 121 Niskin bottles mounted on a rosette with a conductivity, temperature and depth profiler. Samples were collected from $40 \mathrm{~m}$ depth on 28 March 1999 in the Polar Frontal Zone (PF; $49^{\circ} 20.64^{\prime} \mathrm{S}, 20^{\circ} 01.50^{\prime} \mathrm{E}_{\text {; }}$ Stn 157 ) (Giebel et al. 2009) and on 19 April 1999 in the Antarctic Coastal Current (CC) under pack ice (50\% coverage) close to the shelf ice edge, which was $\sim 30 \mathrm{~km}$ distant from the Antarctic continent ( $\left.70^{\circ} 11.29^{\prime} \mathrm{S}, 6^{\circ} 22.16^{\prime} \mathrm{W}_{\text {; }} \mathrm{Stn} 182\right)$ (Giebel et al. 2009). Samples from $40 \mathrm{~m}$ depth were taken because this depth was still in the mixed layer but exhibited lower rates of bacterial production than at $20 \mathrm{~m}$. In situ temperatures were $3.9^{\circ} \mathrm{C}$ at the $\mathrm{PF}$ and $-1.8^{\circ} \mathrm{C}$ at the $\mathrm{CC}$ (Table 1$)$.

\section{Design of the substrate addition experiments}

We examined how the bacterioplankton communities in the 2 regions respond to various substrate additions by monitoring the bacterial growth and the turnover rates of glucose, dissolved free amino acids (DFAA) and protein and by examining how the composition of the bacterioplankton community changed as a function of the added substrates over

Table 1. Environmental and biological properties of the locations of the experiments at the polar Front and the Coastal Current under pack ice (data adopted partly from Giebel et al. 2009). RCA: Roseobacter clade affiliated cluster

\begin{tabular}{|lcc|}
\hline Parameter & $\begin{array}{c}\text { Polar } \\
\text { Front }\end{array}$ & $\begin{array}{c}\text { Coastal } \\
\text { Current }\end{array}$ \\
\hline Temperature $\left({ }^{\circ} \mathrm{C}\right)$ & 3.9 & -1.8 \\
Chlorophyll a $\left(\mu \mathrm{g} \mathrm{l}^{-1}\right)$ & 0.3 & 0.1 \\
Bacterial abundance $\left(10^{5} \mathrm{ml}^{-1}\right)$ & 3.5 & 3.3 \\
Leucine incorporation $\left(\mathrm{pmol} \mathrm{l}^{-1} \mathrm{~h}^{-1}\right)$ & 5.5 & 5.1 \\
Bacterial generation time $(\mathrm{d})$ & 9.8 & 11.9 \\
Glucose turnover rate $\left(\mathrm{d}^{-1}\right)$ & 0.1 & 0.03 \\
RCA $(\%$ Bacteria) & $23^{\mathrm{a}}$ & $18^{\mathrm{a}}$ \\
SAR 11 clade $(\%$ Bacteria $)$ & 7 & 9 \\
a60 m depth & & \\
\hline
\end{tabular}


time. Unfiltered water samples were filled into acidrinsed 21 Nalgene bottles. The following substrates were added at final concentrations of $500 \mu \mathrm{g}$ dry weight $1^{-1}(\sim 20 \mu \mathrm{M}$ C): agarose (agar grade A, BD Sciences), starch (Merck) and peptone (digest of casein; Roth). Agarose was chosen as a model polysaccharide consisting of D-galactose and 3,6-anhydro-L-galactose linked by a $\beta$-glycosidic bond and starch as a model polysaccharide consisting of glucose linked with an $\alpha$-glycosidic bond. An extract of diatoms collected with a centrifuge in the PF and an extract of the green alga Scenedesmus acutus were added to another bottle, each at final concentrations of $\sim 800 \mu \mathrm{g}$ dry weight $\mathrm{l}^{-1}(\sim 30 \mu \mathrm{M} \mathrm{C})$. The frozen extracts were thawed and boiled for $10 \mathrm{~min}$ prior to use. One bottle without any additions was used as a control. Bottles were incubated in the dark at in situ temperature $\left( \pm 1^{\circ} \mathrm{C}\right)$ for $9(\mathrm{PF})$ and $10 \mathrm{~d}(\mathrm{CC})$ and subsampled daily for enumerating prokaryotic cell numbers after DAPI staining by epifluorescence microscopy according to Porter \& Feig (1980). The incubation time was close to the generation time of the ambient bacterioplankton communities (Table 1). As Bacteria constitute the prokaryotic community to a great extent (see 'Results') and Archaea constitute only low fractions of the prokaryotic community in the austral summer and fall (Murray et al. 1998), we use the terms bacteria or bacterioplankton hereafter. Subsampling for other parameters (see the next 2 sections) was done less frequently after Day 4 in the PF experiment. When the experiments were terminated, $500 \mathrm{ml}$ of samples were filtered onto $0.2 \mu \mathrm{m}$ Nuclepore membranes $(47 \mathrm{~mm}$ diameter) and stored at $-20^{\circ} \mathrm{C}$ for DGGE analysis (see 'PCR amplification, DGGE and cluster analysis'). Due to constraints in handling, it was not possible to carry out the experiments with replicate bottles.

\section{Leucine incorporation and turnover rates of DFAA, glucose and protein}

Leucine incorporation was determined from the incorporation of ${ }^{14} \mathrm{C}$-leucine into bacterial biomass according to Simon \& Azam (1989) and as described in detail by Simon \& Rosenstock (2007). We added ${ }^{14} \mathrm{C}$-leucine (specific activity $10.8 \mathrm{GBq} \mathrm{mmol}^{-1}$, Hartmann Analytik) at a final concentration of $10 \mathrm{nM}$ (saturating concentration) in triplicates and a Formalinkilled control to $10 \mathrm{ml}$ of sample and stopped the incubation with Formalin after 4 to $6 \mathrm{~h}$. Uptake was still linear after this incubation time. Fixed samples were filtered onto $0.2 \mu \mathrm{m}$ nitrocellulose filters (Sartorius), rinsed with ice-cold particle-free seawater, extracted with ice-cold 5\% trichloroacetic acid and radioassayed by liquid scintillation counting. The coefficient of variation $\left(\mathrm{CV}_{\mathrm{S}} \mathrm{SD} / \mathrm{mean}\right)$ of the triplicate measurements was $<10 \%$.

Turnover rate constants of DFAA and glucose were determined by measuring the incorporation of a mixture of $16{ }^{3} \mathrm{H}$-DFAA (mean specific activity $1.97 \mathrm{GBq}$ mat C, TRK440, Amersham) and ${ }^{3} \mathrm{H}$-glucose (specific activity $429.0 \mathrm{GBq} \mathrm{mmol}^{-1}$, Amersham) by heterotrophic picoplankton as described by Simon \& Rosenstock (2007). Each radiolabel was added to triplicate $10 \mathrm{ml}$ subsamples and a Formalin-killed control at a final concentration of $0.1 \mathrm{nM}$. Turnover of glucose was measured in a dual label approach together with ${ }^{14} \mathrm{C}$ leucine incorporation. Turnover rate constants of dissolved protein were determined by measuring the incorporation of a ${ }^{14} \mathrm{C}$-algal protein (specific activity $1.63 \mathrm{GBq} \mathrm{mmol}{ }^{-1}$, custom made by Amersham, see Rosenstock \& Simon 2001) according to Simon \& Rosenstock (2007). The radiolabel was added in triplicate to $10 \mathrm{ml}$ subsamples and a Formalin-killed control at $2 \mathrm{nM}$ final concentration (amino acid equivalent). Incubations for all 3 substrates lasted for 4 to $6 \mathrm{~h}$, and samples were further processed as for leucine incorporation. The CV of the triplicate measurements was $<15 \%$. Turnover rate constants of DFAA, glucose and protein were calculated from the incorporated radioactivity divided by the added radioactivity.

\section{Fluorescence in situ hybridization}

In situ hybridization with fluorescent rRNA-targeted oligonucleotide probes was done according to Glöckner et al. (1996). Subsamples of 2 to $5 \mathrm{ml}$ were taken after 4 and $9 \mathrm{~d}$ from the PF microcosm and after 4 and $10 \mathrm{~d}$ from the CC microcosm, filtered onto $0.2 \mu \mathrm{m}$ Nuclepore membranes (25 mm diameter) and fixed by overlaying the filters with $3 \mathrm{ml}$ of a freshly prepared phosphate-buffered saline ( $\mathrm{pH}$ 7.2) $4 \%$ paraformaldehyde solution for $30 \mathrm{~min}$. Thereafter, the filters were washed with Milli-Q water and stored frozen at $-20^{\circ} \mathrm{C}$ until hybridization. The hybridization protocol as described by Glöckner et al. (1996) was applied, and the following group-specific oligonucleotide probes were used: EUB338 for Bacteria (Amann et al. 1990), ALF968 for Alphaproteobacteria (Neef 1997), GAM42a for Gammaproteobacteria (Manz et al. 1992) and CF319a for the Sphingobacteria/Flavobacteria group of the Bacteroidetes phylum (Manz et al. 1996, Amann \& Fuchs 2008). The probes were linked to the N-hydroxysuccinimide ester of the carbocyanine CY3 as the 
fluorochrome. The hybridization procedure included a final staining with DAPI. Cells were viewed using an Axioplan epifluorescence microscope (Zeiss) and the filter sets Zeiss 01 for DAPI and Chroma HQ41007 for Cy3 (Chroma Technology). For each sample, 2 replicates were counted using 10 to 20 view fields with at least 500 DAPI-stained cells per sample. All counts were corrected by subtracting the counts obtained with a negative control (NON338), which never exceeded $1 \%$.

\section{Nucleic acid extraction}

DNA of the bacterial biomass collected on the $0.2 \mu \mathrm{m}$ Nuclepore membranes was extracted following a modified standard protocol of Zhou et al. (1996), which includes treatment with zirconium beads and a mixture of hot $\left(60^{\circ} \mathrm{C}\right)$ phenol-chloroform-isoamyl alcohol in $100 \mathrm{mM}$ sodium phosphate buffer at $\mathrm{pH}$ 8.3. The DNA was precipitated overnight at $-80^{\circ} \mathrm{C}$ after addition of $\mathrm{Na}$-acetate ( $3 \mathrm{M}$ ) and isopropanol $(2.5 \times$ vol $)$. DNA extraction was checked on a $1 \%$ agarose gel. The stock of the extracted DNA was stored at $-80^{\circ} \mathrm{C}$ and subsamples at $-20^{\circ} \mathrm{C}$ until further analysis.

\section{PCR amplification, DGGE and cluster analysis}

The Bacteria-specific primers 341F and 907RM (Muyzer et al. 1998) were used to amplify 550 base pairs (bp) of 16S rRNA gene fragments, which were subsequently separated by DGGE. At the 5 '-end of the GM5F primer, an additional $40 \mathrm{bp}$ GC-rich nucleotide sequence (GC-clamp) was added to stabilize migration of the DNA fragments in DGGE (Muyzer et al. 1993). PCR amplifications were performed with an Eppendorf Mastercycler (Eppendorf) and using RedTaq ${ }^{\mathrm{TM}}$ DNA polymerase (Sigma) as described by Selje \& Simon (2003). We used a touch down PCR program with a decreasing annealing temperature from 65 to $56^{\circ} \mathrm{C}(2$ cycles at each temperature step) and additional 18 cycles at $55^{\circ} \mathrm{C}$ for a total of 38 cycles. The amplicons were examined on $2 \%$ agarose gels stained with ethidium bromide $\left(1 \mu \mathrm{g} \mathrm{ml}^{-1}\right)$. DGGE was performed with the D-Code system (Bio-Rad Laboratories) as described by Selje \& Simon (2003). After electrophoresis, the gels were stained with SYBR Gold (Molecular Probes) and visualized by a BioDoc Analyze Transilluminator (Biometra). A cluster analysis of the DGGE banding patterns was performed based on curves and, after checking for normal distribution of the data, using Pearson correlations and the unweighted pair group method with arithmetic mean with the software GelCompare II, Version 2.5 (Applied Maths). This analysis takes into account the number and intensity of DGGE bands. For further details, see Selje \& Simon (2003).

\section{Cloning, sequencing and phylogenetic analysis}

DGGE bands were excised by a sterile scalpel and suspended in $50 \mu$ l of water of PCR quality (Eppendorf). The accuracy of the bands and the position in the gel were double-checked on DGGE gels. Cloning was done with the Promega pGEM ${ }^{\circledR}$-T-Easy Vector System II according to the manufacturer's advice. Further, we checked the sequences of bands at similar positions by randomly probing several clones of the same ligation reaction. Inserts were reamplified with primers M13F and M13R in two $100 \mu$ l batches using a standard PCR protocol with 30 cycles at an annealing temperature of $50^{\circ} \mathrm{C}$. PCR products were purified with the Qiaquick PCR purification kit (Qiagen) and sequenced using a DNA Sequencer (Model 4200, LI-COR) as described by Selje \& Simon (2003). Sequences were checked for chimera formation with Pintail (www.bioinformatics-toolkit.org/Pintail/) and compared to those in GenBank using the BLAST function of the NCBI server (http://blast.ncbi.nlm. nih.gov/). To increase the reliability of the results, the sequences of the primers were not included in the sequence analysis.

Phylogenetic trees were constructed using the ARB software package (Ludwig et al. 2004, see www.arbhome.de). The backbone tree was calculated with the bootstrap (2000') method using sequences with a minimum length of $1300 \mathrm{bp}$, including type strains of selected phylogenetic groups. For tree calculation, positions were excluded at which $<50 \%$ of all sequences showed the same residues to avoid uncertain alignments. Sequences with $<1300$ bp were added to the backbone tree with the maximum parsimony method using the same filter. As outgroup, 16S rRNA gene sequences of 3 type strains belonging to Cyanobacteria were used.

\section{Nucleotide sequence accession numbers}

The sequences obtained in the present study are available from GenBank under accession no. JQ728958 to JQ728979. 


\section{RESULTS}

The 2 locations of the microcosm experiments differed strongly with respect to water masses, temperature, pack ice cover and other parameters (Table 1). At the CC station, chlorophyll a concentrations, bacterial abundance and activity were lower than at the PF station. Further, as shown in Giebel et al. (2009) by DGGE analyses, the composition of the bacterioplankton community differed strongly between the $\mathrm{PF}$ and $\mathrm{CC}$ regions. At $60 \mathrm{~m}$ depth of the PF station, the Roseobacter clade affiliated (RCA) cluster and the SAR11 clade of Alphaproteobacteria constituted 23 and $7 \%$ of total eubacterial 16S rRNA genes, respectively, and at the $\mathrm{CC}$ station at the same depth, both phylogenetic lineages constituted 18 and $9 \%$, respectively, assessed by quantitative (q)PCR (Giebel et al. (2009). qPCR data for $40 \mathrm{~m}$ depth and DGGE and FISH data for both stations are not available.

\section{Bacterial growth and substrate turnover}

The various treatments resulted in pronounced differences in the response of bacterial growth and substrate turnover rates of both microcosm experiments. In the PF microcosm experiment, a response of most parameters in all treatments did not occur until Days 4 to 6 (Fig. 1). Thereafter, bacterial numbers in the control remained low, whereas leucine incorporation and glucose turnover rates in the control and starch treatment increased strongly, in contrast to the agarose treatment, in which these parameters remained low (Fig. 1A,,$E$ ). Turnover rates of DFAA and protein in the treatments with agarose and starch were 2- to 3-fold higher than in the control until Day 6 and also higher than turnover rates of glucose (Fig. 1G,I). Toward the end, turnover rates of DFAA and protein in the control also increased and reached levels in the range of those of the treatments with agarose and starch. In the treatments with peptone and the diatom extract, bacterial numbers and leucine incorporation reached values 50 to $100 \%$ higher than in the treatments with agarose and starch (Fig. 1B,D). Turnover rates of glucose, DFAA and protein in these treatments simultaneously increased, but values were in the same range as in the other treatments (Fig. $1 \mathrm{~F}, \mathrm{H}, \mathrm{J}$ ). In the treatment with the Scenedesmus extract, respective values remained lower than in the treatments with peptone and the diatom extract and similar to those of the treatments with agarose and starch, except for DFAA turnover rates (Fig. 1B,D,F,H,J).
In the CC microcosm experiment, the response of bacterial growth and substrate turnover rates to the various substrate additions started earlier than in the PF microcosms, in most cases after 3 to $4 \mathrm{~d}$, and responses were higher than in the $\mathrm{PF}$ experiment (Fig. 2). Whereas bacterial numbers in the control and the agarose treatment exhibited only minor changes, those in the treatments with starch and the Scenedesmus extract increased 3-fold and in those with peptone and the diatom extract even more than 4 -fold (Fig. 2A,B). Rates of leucine incorporation and glucose turnover in the agarose treatment remained lower than in the other treatments, and highest responses occurred in the treatments with peptone and the diatom extract (Fig. 2C-F). Temporal patterns of the latter, however, differed strongly. Turnover rates of DFAA and protein in all treatments exhibited rather similar temporal patterns with an increase after Day 4 and lowest rates in the control (Fig. 2G-J). Protein turnover rates in the treatments with peptone and the Scenedesmus and diatom extracts reached values on Day 7 that were 5 -fold higher than in the control and the other treatments. Values in the control remained lower than in the treatments with substrate additions but also increased after Day 4, as did leucine incorporation and glucose turnover in the control. Data of DFAA and protein turnover rates are only available until Day 7.

\section{Bacterial community composition}

The composition of the bacterial community in both experiments was analyzed by FISH on Day 4, the end of the first phase with little changes in growth and substrate turnover rates, and at the end of the experiments. In the PF experiment, 41 to $51 \%$ of DAPI cell counts were detected by the EUB probe in the control, agarose and starch treatments on Day 4 and 63 to $73 \%$ in the other treatments (Table 2). On Day 9, the detection efficiency in the various treatments was 73 to $92 \%$, with lowest values in the control and agarose treatments. Sphingobacteria/Flavobacteria and Alphaproteobacteria constituted $\sim 20 \%$ of DAPI cell counts in the control on Day 4, but in the treatments with agarose and starch, Alphaproteobacteria clearly dominated with 30 and $25 \%$ and the 2 other groups made up $<17 \%$ (Fig. 3). In the other treatments, Sphingobacteria/Flavobacteria dominated and constituted 25 to $46 \%$. In the treatments with peptone and the Scenedesmus extract, Alphaproteobacteria were the second most abundant group, 

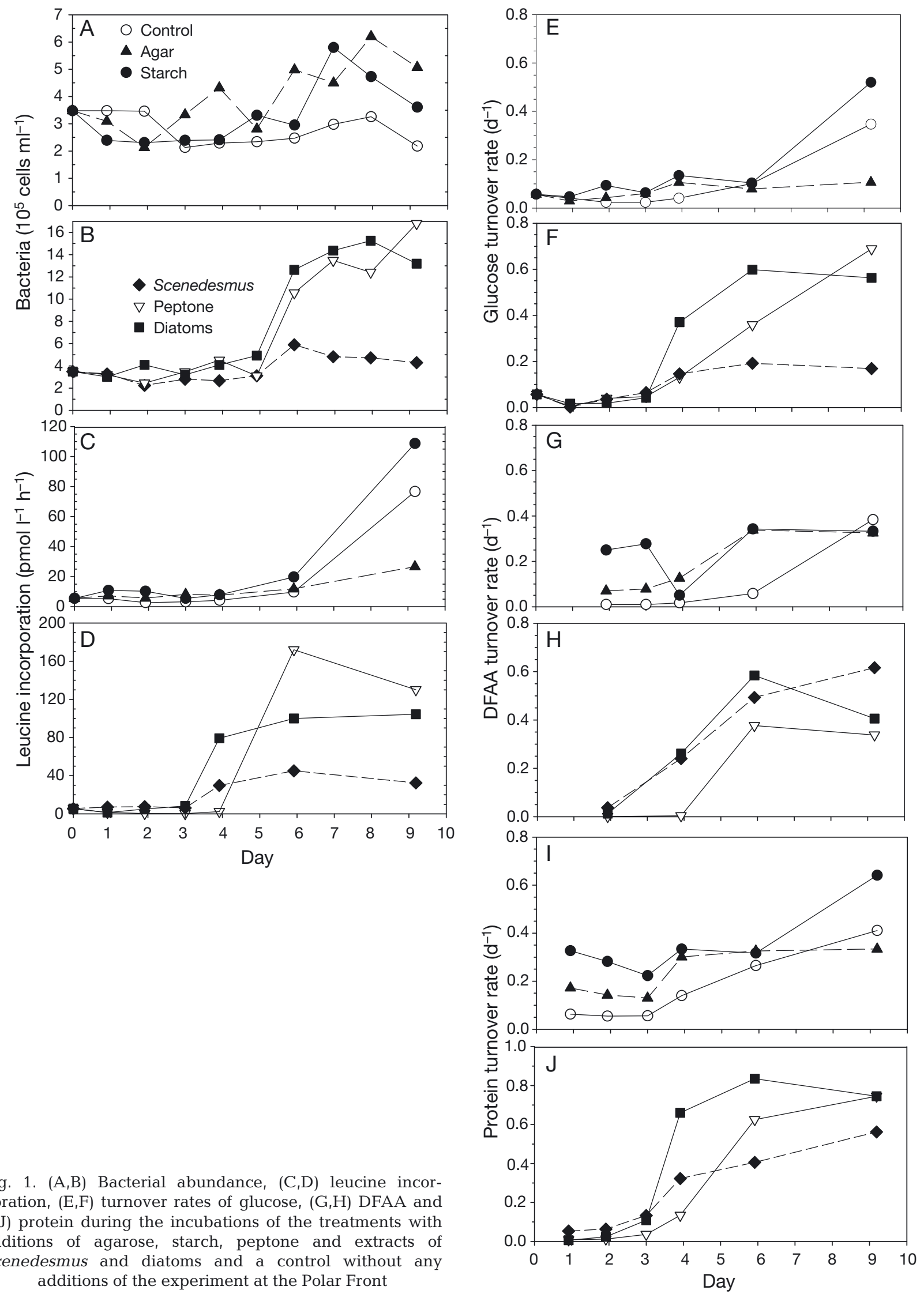

1. $(A, B)$ Bacterial abundance, $(C, D)$ leucine incorporation, $(\mathrm{E}, \mathrm{F})$ turnover rates of glucose, $(\mathrm{G}, \mathrm{H})$ DFAA and $(\mathrm{I}, \mathrm{J})$ protein during the incubations of the treatments with additions of agarose, starch, peptone and extracts of Scenedesmus and diatoms and a control without any additions of the experiment at the Polar Front 


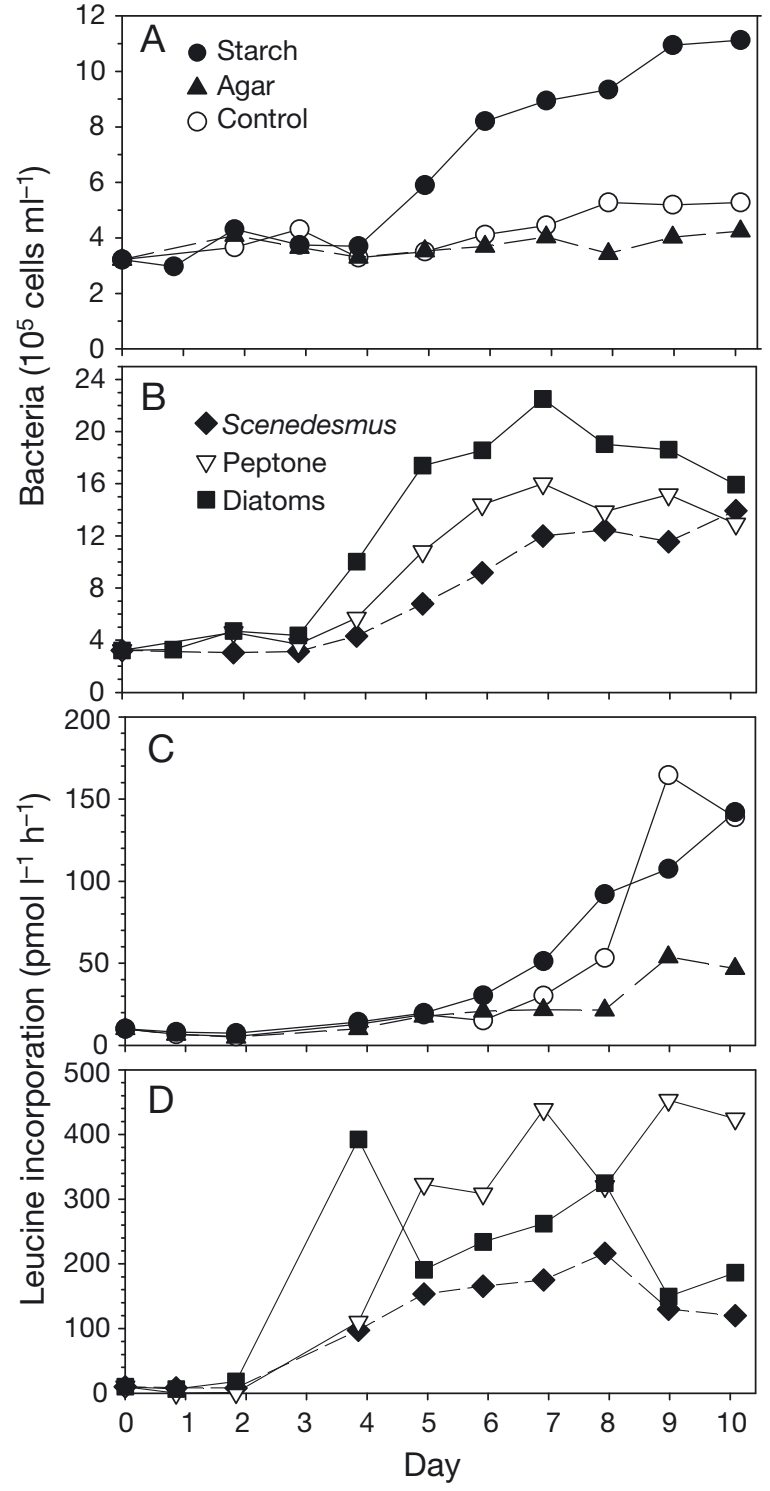

Fig. 2. $(\mathrm{A}, \mathrm{B})$ Bacterial abundance, $(\mathrm{C}, \mathrm{D})$ leucine incorporation, $(\mathrm{E}, \mathrm{F})$ turnover rates of glucose, $(\mathrm{G}, \mathrm{H})$ DFAA and $(\mathrm{I}, \mathrm{J})$ protein in the experiment in the Coastal Current. See Fig. 1 for more detail
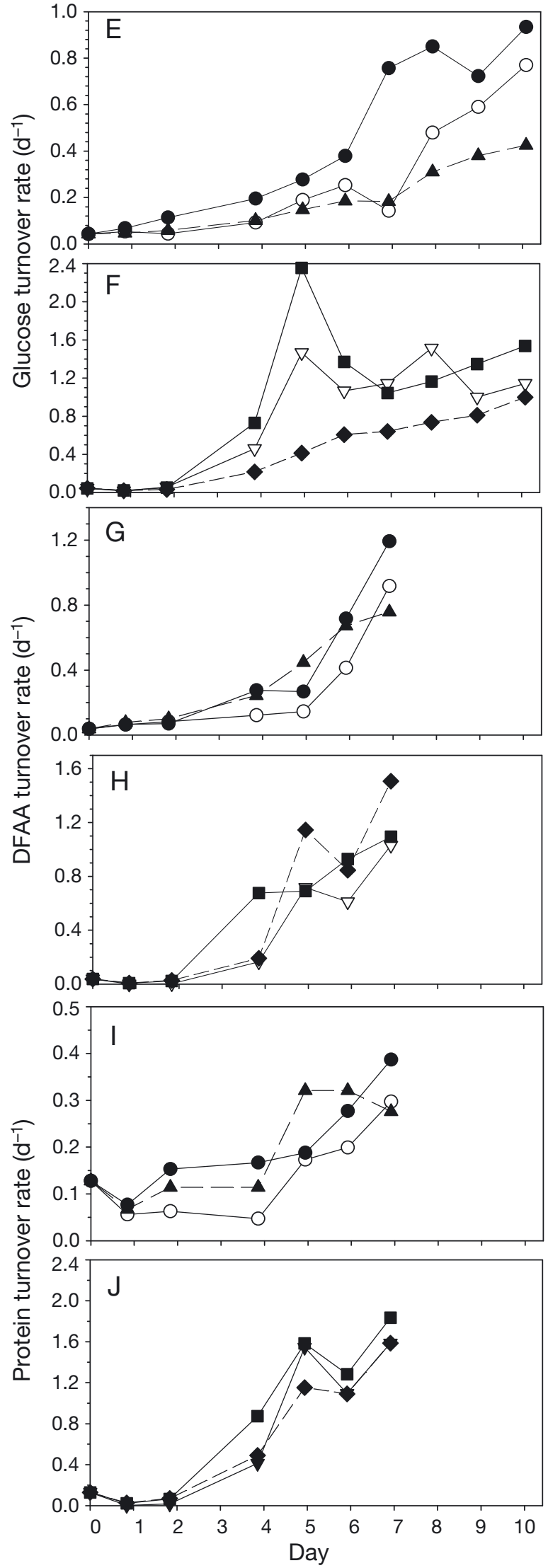
Table 2. Relative proportions of Bacteria (enumerated by probe EUB338; mean \pm SD) on Day 4 and the final sampling on Days 9 or 10, in the microcosm experiments at the Polar Front and the Coastal Current in all treatments and the control

\begin{tabular}{|c|c|c|}
\hline & \multicolumn{2}{|c|}{ Bacteria (\% DAPI cell counts) } \\
\hline & Day 4 & Final sample \\
\hline Polar Front & & Day 9 \\
\hline Control & $50.8 \pm 13.2$ & $74.0 \pm 13.3$ \\
\hline Starch & $40.7 \pm 8.5$ & $80.6 \pm 16.9$ \\
\hline Agarose & $46.7 \pm 14.9$ & $72.8 \pm 16.0$ \\
\hline Peptone & $63.5 \pm 15.9$ & $92.4 \pm 10.1$ \\
\hline Diatoms & $72.6 \pm 10.1$ & $88.2 \pm 8.8$ \\
\hline Scenedesmus & $63.0 \pm 13.8$ & $81.4 \pm 15.4$ \\
\hline Coastal Current & & Day 10 \\
\hline Control & $31.1 \pm 3.9$ & $78.8 \pm 14.0$ \\
\hline Starch & $66.2 \pm 13.1$ & $84.3 \pm 8.6$ \\
\hline Agarose & $40.2 \pm 8.9$ & $72.8 \pm 17.5$ \\
\hline Peptone & $60.4 \pm 22.4$ & $80.4 \pm 8.6$ \\
\hline Diatoms & $74.1 \pm 12.3$ & $84.1 \pm 16.6$ \\
\hline Scenedesmus & $63.6 \pm 17.1$ & $89.0 \pm 9.9$ \\
\hline
\end{tabular}

whereas in that with the diatom extract, Gammaproteobacteria were the second most abundant. On Day 9, the composition had changed substantially because in the control and all treatments, except aga- rose, Sphingobacteria/Flavobacteria strongly dominated and constituted 34 to $69 \%$ (Fig. 3). For the agarose treatment, only data for Sphingobacteria/ Flavobacteria are available, constituting only $24 \%$, and for the control, data on Gammaproteobacteria are missing. On Day 4 , the 3 probes together constituted 46 to $100 \%$ of DAPI cell counts with the lowest fractions in the starch and peptone treatments and the highest fraction in that with the diatom extract. Respective cumulative proportions amounted to $60-100 \%$, with highest values in the starch and peptone treatments.

In the CC microcosm experiment, cumulative proportions of the 3 probes were $72 \%$ of DAPI cell counts in the agarose treatment and at least $85 \%$ in all other treatments and the control (Fig. 3). On Day 4, Alphaproteobacteria dominated in the control and the agarose treatment with 58 and $36 \%$, respectively, but on Day 10, Sphingobacteria/Flavobacteria accounted for significantly higher percentages than Alphaproteobacteria. In the other treatments, Sphingobacteria/Flavobacteria constituted highest percentages already on Day 4, ranging from 46 to $59 \%$, and further increased until Day 10, accounting for 72 to $88 \%$ of DAPI cell counts (Fig. 3). Gammapro-
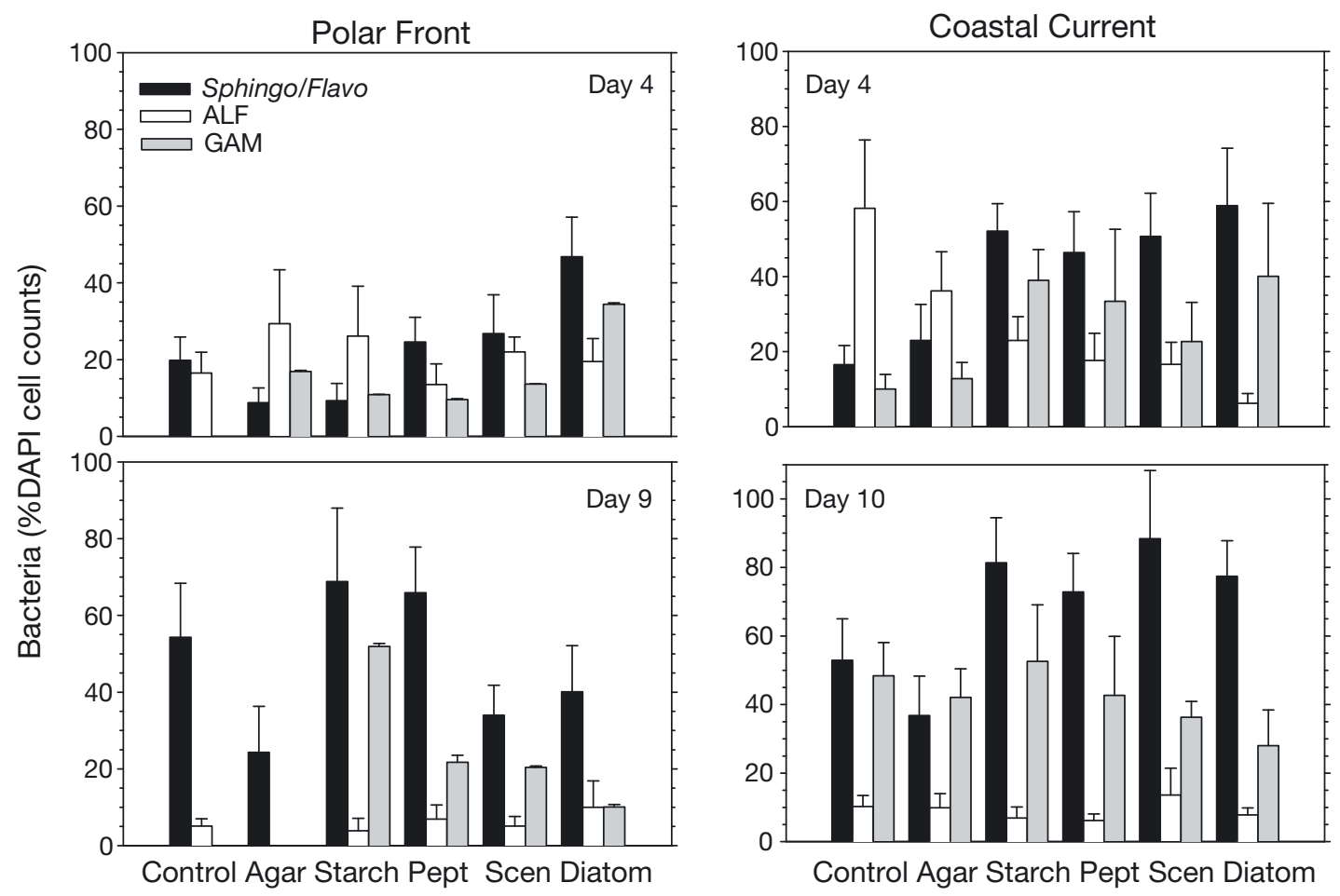

Fig. 3. Bacterial numbers (\% of DAPI cell counts) of Sphingobacteria/Flavobacteria (Sphingo/Flavo), Alphaproteobacteria (ALF) and Gammaproteobacteria (GAM) at the Polar Front and the Coastal Current on Day 4 and at the final sampling of the experiment (Polar Front on Day 9; Coastal Current on Day 10) in the treatments with additions of agarose, starch, peptone (Pept) and extracts of Scenedesmus (Scen) and diatoms and a control without any additions 
Table 3. Number of DGGE bands at the final sampling of the microcosm experiment at the Polar Front and the Coastal Current in all treatments and the control

\begin{tabular}{|lcc|}
\hline & Polar Front & Coastal Current \\
\hline Control & 9 & 15 \\
Starch & 14 & 14 \\
Agarose & 9 & 14 \\
Peptone & 9 & 14 \\
Diatoms & 10 & 16 \\
Scenedesmus & 11 & 13 \\
\hline
\end{tabular}

teobacteria were the second most abundant group in these treatments, with fractions of 23 to $40 \%$ on Day 4 and of 28 to $53 \%$ on Day 10. Fractions of Alphaproteobacteria decreased from Days 4 to 10 in the control and all treatments and finally constituted $<14 \%$.

The DGGE and cluster analysis further substantiated that pronounced differences occurred between the bacterial communities in both experiments and among the various treatments. The number of bands at the termination of the PF experiment ranged from 9 to 14, with lowest numbers in the control and the agarose and peptone treatments and highest numbers in the starch treatment (Table 3, Fig. 4A). In the CC experiment, the number of bands ranged between 13 and 16 at the final sampling, with lowest numbers in the treatment with Scenedesmus extract and highest numbers in that with diatom extract. The starch addition yielded almost similar numbers of bands in both experiments. In the control and the other treatments, the number of bands in the CC experiment was consistently higher than in the PF experiment. A cluster analysis showed that the banding patterns differed strongly between both experiments (Fig. 4B). In the PF experiment, the treatments with starch, peptone and the diatom and Scenedesmus extract clustered together, with a similarity of the banding patterns of $>70 \%$. Banding patterns of the control and the agarose treatment differed strongly from those of the other treatments and also from each other.
Banding patterns of the various treatments in the CC experiment exhibited 2 subclusters, one with a similarity of $>65 \%$, including peptone and the Scenedesmus and diatom extract, and another with the other treatments and a similarity of $>70 \%$.

A total of 22 bands were excised and sequenced. Six sequences affiliated to Flavobacteria (ANT-PF1, -PF18, -CC6, -CC7, CC16 and -CC20), 2 to Cytophagales of the Bacteroidetes phylum (ANT-PF19 and -CC8) and 5 to the Roseobacter clade of Alphaproteobacteria (ANT-PF2, -PF-3, -PF9, -PF10 and -PF22). Further, 9 sequences affiliated to Gammaproteobacteria, of which 4 belonged to the Pseudoalteromonadaceae (ANT-PF4, -PF13, -PF14 and -PF15), 3 to the Colwellia cluster of Alteromonadaceae (ANT-PF5,

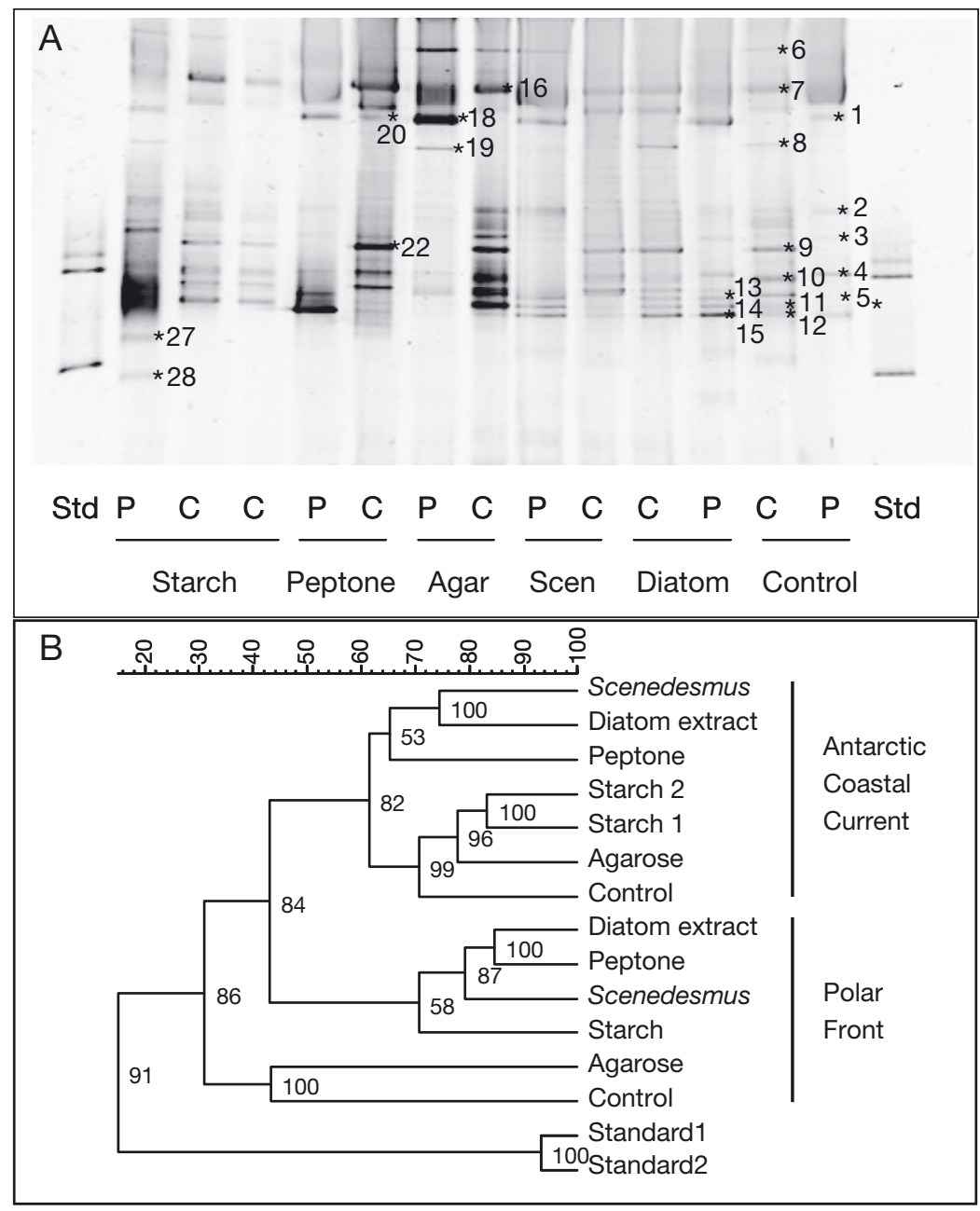

Pearson correlation (Opt:0.82\%) [0.0\%-100.0\%]

Fig. 4. (A) DGGE banding patterns and (B) cluster analysis of bacterial communities at the final sampling of the experiment at the Polar Front (P) on Day 9 and in the Coastal Current (C) on Day 10 in the treatments with additions of agarose, starch, peptone and extracts of Scenedesmus (Scen) and diatoms and a control without any additions. Std: standard for the DGGE analysis. ${ }^{*}$ and numbers indicate excised bands that were sequenced 


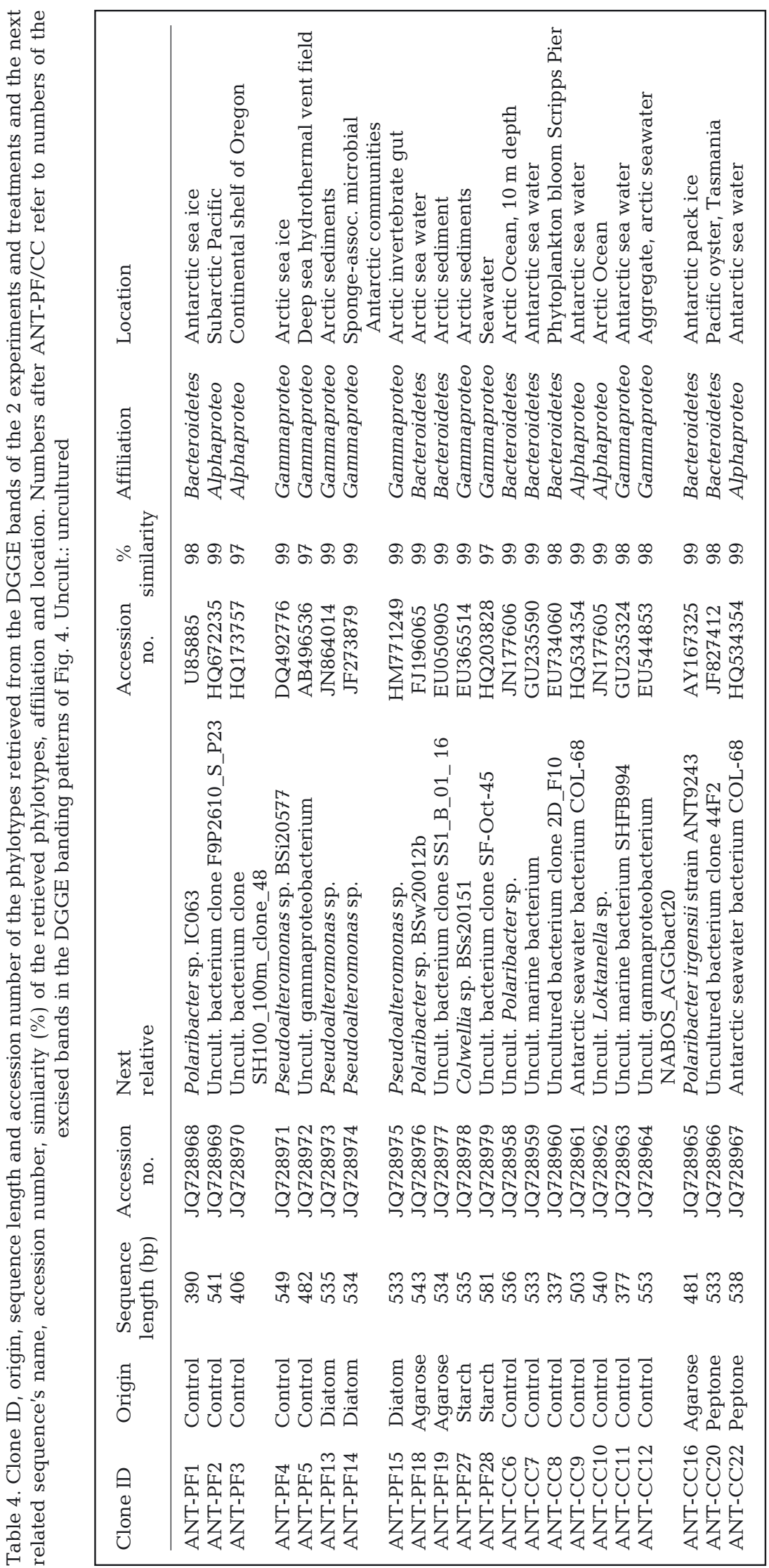

-PF27 and -PF28) and 2 to other lineages of Gammaproteobacteria (ANTCC11 and -CC12) (Table 4, Fig. 5). In most cases, the next related phylotypes originate from Antarctic, Arctic, subarctic, upwelling and deep sea habitats.

Several bands appeared in all treatments of a given experiment, such as in the PF experiment bands ANT-PF1 and -PF18 and in the CC experiment bands ANT-CC7, -CC16, ANT-CC9, -CC22 and ANT-CC10, although with different intensities (Fig. 4A). Other bands were present only in a few treatments, such as band ANT-PF4 in the control and the treatment with diatom extract. Similar bands in both experiments appeared only in the treatment with the diatom extract, with bands ANT-PF13, -PF14 and -PF15.

\section{DISCUSSION}

\section{Response of bacterial growth and substrate turnover to biopolymer additions}

Micro- or mesocosm experiments are a well established approach to examine the response in growth, substrate turnover and composition of bacterioplankton communities to altered substrate regimes relative to ambient conditions. In most cases, either a phytoplankton bloom was experimentally induced by the addition of inorganic nutrients or by inoculation with distinct phytoplankton species (e.g. Lebaron et al. 1999, Riemann et al. 2000, Murray et al. 2007) or selected simple inorganic nutrients and/or organic substrates, such as glucose and/or DFAA, were applied (e.g. Church et al. 2000, Massana et al. 2001, Ducklow et al. 2011, GómezConsarnau et al. 2012). More than 2 treatments with different organic compounds were rarely applied, such as dissolved protein and starch (Pinhassi et al. 1999) or other simple 


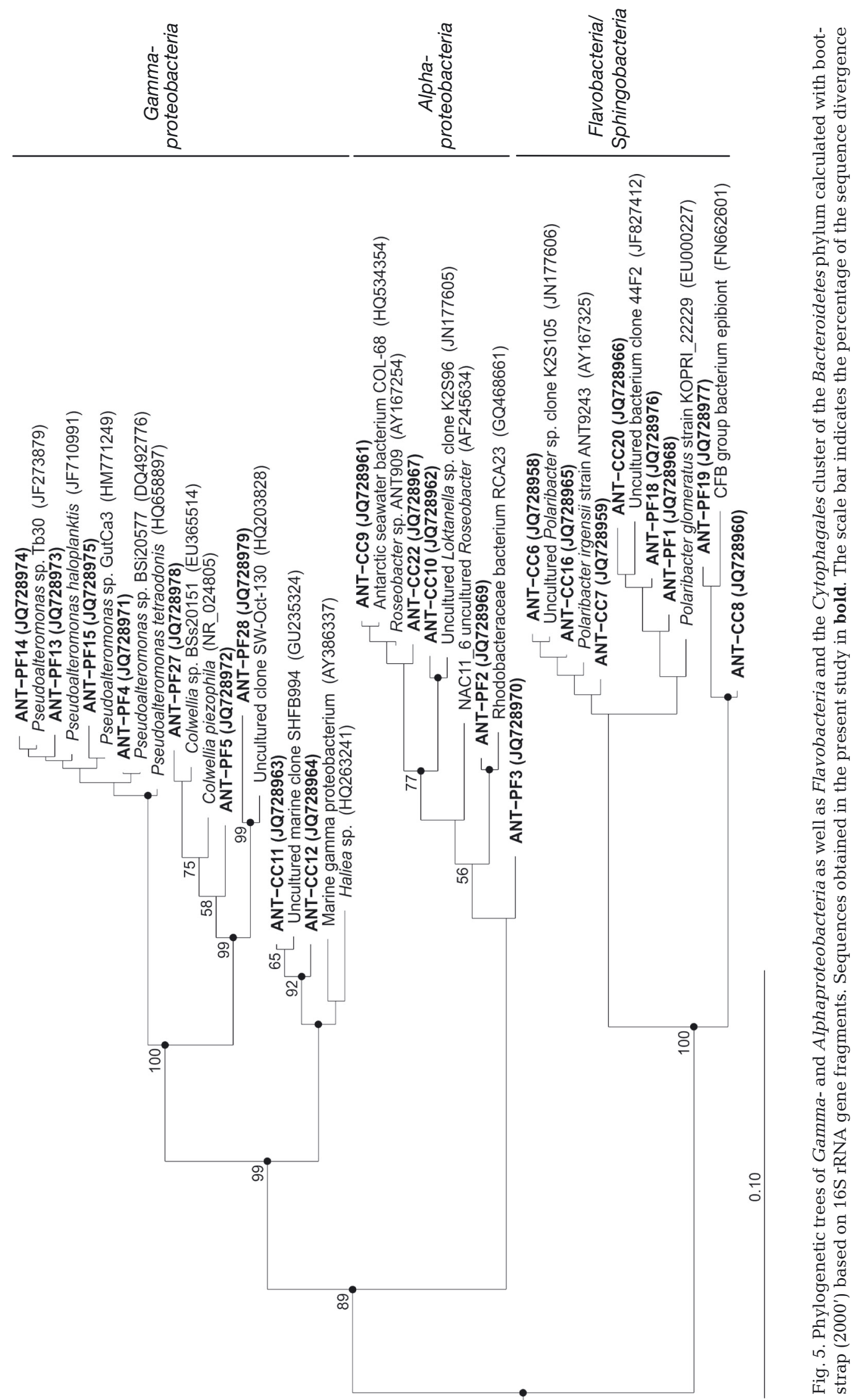


organic acids and amino acids (Gómez-Consarnau et al. 2012). To examine how bacterioplankton communities in the Southern Ocean adapt to various biopolymers potentially available to these communities and in higher concentrations than monosaccharides and DFAA (Simon \& Rosenstock 2007), we applied agarose, starch, peptone and extracts of Scenedesmus and phytoplankton from the PF dominated by diatoms. The growth response in the CC experiment was more pronounced than in the PF experiment, as reflected in bacterial numbers, leucine incorporation and substrate turnover rates, despite the lower temperature. The conditions controlling bacterioplankton growth appeared to favor bacterial growth and substrate turnover more in the $\mathrm{CC}$ with lower phytoplankton biomass than at the PF. These conditions may have included protozoan grazing, phage infection and limitation by inorganic nutrients, which were not assessed during the experiments.

Massana et al. (2001) examined the growth response of bacterioplankton communities to additions of acetate and glucose at various locations in the Southern Ocean, including the polar frontal region and ice edge, but found little difference among the various locations. However, strong differences of the growth response of bacterioplankton communities to additions of glucose and DFAA were reported between the Subtropical and Polar Front by Church et al. (2000). At the Subtropical Front, bacterial growth was strongly enhanced by these substrates, but growth was not enhanced at all at the PF.

With respect to the individual substrate additions in our experiments, starch supported growth better than agarose at both locations, as reflected by bacterial numbers, leucine incorporation and glucose turnover. However, turnover rates of DFAA and protein did not co-vary with the former parameters and thus appear not to reflect the carbohydrate metabolism of the bacteria but rather their amino acid metabolism. Agarose and starch differ with respect to their glycosidic bond and monosaccharide building blocks. The trait of cleaving the $\alpha$-glycosidic bond of starch and taking up the cleaved glucose appears to be more widespread in the bacterioplankton communities in the Southern Ocean than that of cleaving the $\beta$-glycosidic bond of agarose and taking up its building block galactose. Galactose constitutes only 9 to $22 \mathrm{~mol} \%$ of dissolved combined monosaccharides in the Southern Ocean as compared to glucose with at least $35 \mathrm{~mol} \%$ but often 45 to $73 \mathrm{~mol} \%$ (Kirchman et al. 2001, Simon \& Rosenstock 2007). It appears to be a more general phenomenon that bacterioplankton prefer glucose relative to galactose as turnover rates of glucose are 2- to 3-fold higher than those of galactose (Bunte \& Simon 1999).

With respect to the complex substrate additions, peptone and the diatom extract supported bacterial growth much better than the Scenedesmus extract, starch or agarose in both experiments, as reflected by bacterial abundance, leucine incorporation and glucose turnover but not by that of DFAA and protein, except for the latter in the PF experiment. The growth response to the addition of the Scenedesmus extract was similar to that of starch. A possible reason for the lower bacterial growth yield on the Scenedesmus extract may be that the $\mathrm{C}: \mathrm{N}$ ratio of this alga was presumably rather high. The C:N ratio varies between 7 and 25, depending on the N-limitation of the alga (Adams \& Sterner 2000). Our extract was from the stationary phase of a culture growing under $\mathrm{N}$-limitation, thus being of lower quality, i.e. C and $\mathrm{N}$ supply was not in balance for protein synthesis. In contrast, the C:N ratio of the peptone and diatom extract presumably was lower and closer to the requirements for protein synthesis. The C:N ratio of peptone is $\sim 3$ (Zapata-Vélez \& Trujillo-Roldán 2010), and that of particulate organic matter from the PF dominated by diatoms is $\sim 7$ (Rubin 2003). Our observation of an enhanced growth response of the bacterioplankton to the additions of peptone and the diatom extract relative to starch and agarose is in line with results of Pinhassi et al. (1999). These authors found that dissolved protein (bovine serum albumin) supported bacterioplankton growth in the Southern California Bight much better than starch. Polysaccharides, such as starch and agarose, are only a C source for bacteria and need a complementation of an $\mathrm{N}$ source, such as ammonium, for amino acid and protein synthesis, provided that the bacteria are capable of cleaving the glycosidic bond and taking up the mono- and/or oligosaccharides. Our observations of the enhanced bacterial growth response to the addition of peptone and the diatom extract relative to the other substrate additions is also consistent with findings of Simon \& Rosenstock (2007). These authors found that bacterioplankton production in the Southern Ocean is much more closely correlated to concentrations and incorporation of dissolved protein than to concentrations of dissolved carbohydrates. Peptone and dissolved proteins are basically identical substrates, and 45 to $60 \%$ of the biomass of diatoms consists of protein (Renaud et al. 1999). Our results do not provide any evidence that the enhanced concentrations of the added extracts of diatoms and Scenedesmus favored growth more than the other substrates. The diatom extract and peptone 
additions yielded the highest response, whereas the Scenedesmus extract yielded a lower response similar to that of starch.

We note that in the control of both experiments, the leucine incorporation and substrate turnover rates increased toward the end, and the composition of the bacterial community changed relative to Day 4 . This indicates that even without substantial changes in bacterial numbers, the metabolic activities and structure of the bacterial communities underwent alterations, possibly induced by mortality, such as grazing and phage infection, and by recycling of the nutrients released by these cell lysing processes.

The experiments were run without replicates because of various constraints. However, the general outcome of both experiments was similar. Further, in other comparable experiments, including those carried out in the Southern Ocean, replicates usually agreed fairly well (Pinhassi et al. 1999, Riemann et al. 2000, Massana et al. 2001, Ducklow et al. 2011). Therefore, we assume that the pronounced differences among the various treatments in our experiments are sound and much greater than just among replicates of a single treatment.

\section{Response of the bacterial community composition to biopolymer additions}

Enrichments with simple and/or complex substrates have been applied for more than a decade to examine how bacterioplankton communities respond structurally to growth conditions differing from the ambient situation. Massana et al. (2001) and Ducklow et al. (2011) found that the addition of glucose and acetate favored growth of distinct populations of Flavobacteria and Gammaproteobacteria in the Southern Ocean. Abell \& Bowman (2005b) examined the decomposition of diatom-derived detritus by bacterial communities in the Southern Ocean at the Polar Front, the ice edge and in pack ice and reported that Flavobacteria were the main decomposers at the Polar Front, whereas Gammaproteobacteria dominated at the other locations. Flavobacteria and Sphingobacteria were most responsive during an experimentally induced diatom bloom in the Southern California Bight of the Pacific (Riemann et al. 2000). At the same location, populations of Cytophagales and Flexibacteriales were the most responsive bacterial lineages of the entire community when grown on protein (Pinhassi et al. 1999), whereas starch did not support growth of these bacterial communities at all.
The FISH and DGGE data and the cluster analysis of our results show that the bacterial communities at the $\mathrm{PF}$ and in the $\mathrm{CC}$ under pack ice underwent changes during growth on the various substrates and exhibited distinctly different community structures as a result of the response to different substrate regimes. In both experiments and all treatments, there was a general trend to decreasing proportions of Alphaproteobacteria during the incubation and to a dominance of Bacteroidetes and more specifically Flavobacteria and Cytophagales, followed by Pseudoalteromonadales and members of the Colwellia cluster of Gammaproteobacteria. This dominance was most pronounced in the $\mathrm{CC}$ experiment and the treatments with the most active growth and highest bacterial numbers, i.e. all treatments except the agarose addition and the control. Despite this general similarity between both experiments, they exhibited distinct differences with respect to the detected bacterial populations of the 3 major phylogenetic groups. The number of DGGE bands in the PF experiment was consistently lower than in the CC experiment, and the detected phylotypes of all 3 major phylogenetic groups clustered well separately for both experiments except in 2 cases of Flavobacteria and Cytophagales. The PF experiment exhibited a higher diversity, i.e. number of DGGE bands, of Gammaproteobacteria compared to the CC experiment, whereas the latter exhibited a higher diversity of Flavobacteria and Cytophagales. These results of distinct adaptations are in line with previous observations from mesocosm experiments with additions of simple and complex substrates but provide a much more detailed picture with respect to the polymeric substrates applied and the bacterial community structure.

Flavobacteria and Sphingobacteria are known to be able to consume polymeric substrates (Kirchman 2002) and to be superior to Gamma- and Alphaproteobacteria in consuming protein (Cottrell \& Kirchman 2000). The former phylogenetic lineages constitute high proportions of the bacterioplankton in the Southern Ocean, often exceeding Gamma- and Alphaproteobacteria (Simon et al. 1999, Abell \& Bowman 2005a, Straza et al. 2010). Straza et al. (2010) showed that Flavobacteria and Sphingobacteria, together with Gammaproteobacteria, dominate the consumption of dissolved protein around the Antarctic Peninsula. Hence, the results of our study are in line with these observations but extend them by showing that members of Flavobacteria and Cytophagales and of Pseudomonadales and the Colwellia cluster of Gammaproteobacteria can grow on a great variety of complex substrates in the 
Southern Ocean, although with different growth rates and yields. Our observations shed light on the great flexibility of these phylogenetic lineages in their substrate spectra and help to explain their success in this globally coldest oceanic region. Most bands in the DGGE banding patterns were present in all treatments of a given experiment, and the number of bands did not systematically decrease relative to the control. These results are in contrast to those of Ducklow et al. (2011), who found that in glucose amended mesocosms, the bacterial diversity became reduced to $<50 \%$ of the number of phylotypes of the ambient bacterioplankton community after $10 \mathrm{~d}$ near Palmer station at the Antarctic Peninsula. We are aware of the fact that DGGE only detects phylotypes with a proportion of $\sim 1 \%$ of the bacterial community (Muyzer et al. 1993), thus missing a considerable fraction of the less abundant members of the community. Two recent studies, carried out in the Southern Ocean, compared the DGGE approach with approaches of higher sensitivity in bacterial community analysis, such as pyrosequencing (Ghiglione \& Murray 2012), length heterogeneity polymerase chain reaction and capillary electrophoresis single-strand conformation polymorphism (CE-SSCP) (Ducklow et al. 2011). In both studies, cluster analyses of the DGGE and the other approaches yielded similar results, thus indicating that DGGE is a valid approach to analyze the bacterioplankton community composition.

Under conditions of low substrate availabilities, e.g. non-phytoplankton bloom conditions, Alphaproteobacteria and in particular members of the SAR11 and Roseobacter clades, such as the RCA and NAC11-7 clusters, can constitute proportions of similar of even higher magnitude than Flavobacteria and Gammaproteobacteria (West et al. 2008, Giebel et al. 2009). Such conditions existed at both locations where samples for the experiments were collected, as the SAR11 clade and the RCA cluster constituted $\sim 30 \%$ of Bacteria in the ambient bacterioplankton community (Giebel et al. 2009). These conditions were still reflected in the PF experiment in the control and the treatments with agarose and starch and in the $\mathrm{CC}$ experiment in the control and the treatment with agarose on Day 4, when bacterial numbers were still low, as Alphaproteobacteria constituted similar or higher proportions than the other 2 phylogenetic groups.

Grazing and phage infection may have also affected dynamics of bacterial growth and community composition in the various treatments of both experiments because we used unfiltered water samples. A detectable impact of grazing and phage infection in a microcosm approach requires a very active initial bacterial community, a growth response of the bacterial community or, if selective mortality occurs, mortality of the bacterial target groups. The initial bacterial communities had a bulk generation time of 9 to $10 \mathrm{~d}$ and thus cannot be considered as very active. Flavobacteria and Sphingobacteria were most responsive in both experiments, followed by Gammaproteobacteria, which increased in relative abundance in all treatments of both experiments except in treatments with the diatom extract. In contrast, Alphaproteobacteria decreased in relative abundance in all treatments between Day 4 and the end. These findings are in line with other experimental and field observations (see section 'Response of the bacterial community composition to biopolymer additions'). Therefore, we assume that grazing and phage infection did not affect our general results on the bacterial community composition even though we cannot rule out a minor influence on the bacterial growth response, in particular toward the end of both experiments.

\section{CONCLUSIONS}

Our experiments showed that bacterioplankton communities at the PF and in the $\mathrm{CC}$ exhibited distinct responses to the addition of various biopolymers, thus supporting our hypothesis of different growth responses of these communities to simple (C only) and complex $(\mathrm{C}+\mathrm{N})$ biopolymeric substrate additions. In both experiments, complex substrates and in particular peptone and a diatom extract supported growth best, whereas agarose supported growth least. Flavobacteria and Cytophagales of the Bacteroidetes phylum and Pseudomonadales and the Colwellia cluster of Gammaproteobacteria were the major phylogenetic lineages proliferating on these biopolymeric substrates. However, even in the treatment with agarose and the lowest growth response and in the control, shifts in the bacterial community structure toward the mentioned phylogenetic lineages occurred. These results indicate that bacterioplankton communities in the Southern Ocean are able to adapt to a great variety of substrates. Our findings shed further light on observations that distinct lineages of Flavobacteria and Cytophagales and of Gammaproteobacteria are the main players in organic matter decomposition during events of high inputs of polymeric substrates, such as during phytoplankton blooms and pack ice melting. 
Acknowledgements. We thank the crew of RV 'Polarstern' for their excellent cooperation and help on shipboard, T. Brinkhoff for introduction to the Pintail software for checking chimera sequences and S. Breider and H. A. Giebel for assistance with the submission of the sequences to GenBank. We are most grateful to constructive suggestions of 4 reviewers on earlier versions of this publication. This work was supported by grants from Deutsche Forschungsgemeinschaft (Si 360/7-1, Si 360/10-1, TRR 51 Roseobacter).

\section{LITERATURE CITED}

Abell GCJ, Bowman JP (2005a) Ecological and biogeographic relationships of class Flavobacteria in the Southern Ocean. FEMS Microbiol Ecol 51:265-277

Abell GCJ, Bowman JP (2005b) Colonization and community dynamics of class Flavobacteria on diatom detritus in experimental mesocosms based on Southern Ocean seawater. FEMS Microbiol Ecol 53:379-391

> Adams TS, Sterner RW (2000) The effect of dietary nitrogen content on trophic level ${ }^{15} \mathrm{~N}$ enrichment. Limnol Oceanogr 45:601-607

Amann R, Fuchs BM (2008) Single-cell identification in microbial communities by improved fluorescence in situ hybridization techniques. Nat Rev Microbiol 6:339-348

Amann RI, Krumholz L, Stahl DA (1990) Fluorescent oligonucleotide probing of whole cells for determinative, phylogenetic, and environmental studies in microbiology. J Bacteriol 172:762-770

> Bunte C, Simon M (1999) Bacterioplankton turnover of dissolved free monosaccharides in a mesotrophic lake. Limnol Oceanogr 44:1862-1870

> Church MJ, Hutchins DA, Ducklow HW (2000) Limitation of bacterial growth by dissolved organic matter and iron in the Southern Ocean. Appl Environ Microbiol 66:455-466

Cottrell MT, Kirchman DL (2000) Natural assemblages of marine proteobacteria and members of the CytophagaFlavobacter cluster consuming low- and high-molecularweight dissolved organic matter. Appl Environ Microbiol 66:1692-1697

Ducklow HW, Carlson C, Church M, Kirchman D, Smith D, Steward G (2001) The seasonal development of the bacterioplankton bloom in the Ross Sea, Antarctica, 19941997. Deep-Sea Res II 48:4199-4221

> Ducklow HW, Myers KMS, Erickson M, Ghiglione JF, Murray $\mathrm{AE}$ (2011) Response of a summertime Antarctic marine bacterial community to glucose and ammonium enrichment. Aquat Microb Ecol 64:205-220

> Ducklow HW, Schofield O, Vernet M, Stammerjohn S, Erickson M (2012) Multiscale control of bacterial production along the western Antarctic Peninsula: a regional and decadal investigation. J Mar Syst 98-99:26-39

> Ghiglione JF, Murray AE (2012) Pronounced summer to winter differences and higher wintertime richness in coastal Antarctic marine bacterioplankton. Environ Microbiol 14:617-629

> Giebel HA, Brinkhoff T, Zwisler W, Selje N, Simon M (2009) Distribution of Roseobacter RCA and SAR11 lineages and distinct bacterial communities from the subtropics to the Southern Ocean. Environ Microbiol 11:2164-2178

Glöckner FO, Amann R, Alfreider A, Pernthaler J, Psenner R, Trebesius K, Schleifer KH (1996) An in situ hybridization protocol for detection and identification of planktonic bacteria. Syst Appl Microbiol 19:403-406
Gómez-Consarnau L, Lindh MV, Gasol JM, Pinhassi J (2012) Structuring of bacterioplankton communities by specific dissolved organic carbon compounds. Environ Microbiol 14:2361-2378

> Kirchman DL (2002) The ecology of Cytophaga-Flavobacteria in aquatic environments. FEMS Microbiol Ecol 39: 91-100

> Kirchman DL, Meon B, Ducklow HW, Carlson CA, Hansell DA, Steward GF (2001) Glucose fluxes and concentrations of dissolved combined neutral sugars (polysaccharides) in the Ross Sea and Polar Front Zone, Antarctica. Deep-Sea Res II 48:4179-4197

> Kirchman DL, Moran XAG, Ducklow HW (2009) Microbial growth in the polar oceans role of temperature and potential impact of climate change. Nat Rev Microbiol 7: $451-459$

Lebaron P, Servais P, Troussellier M, Courties C and others (1999) Changes in bacterial community structure in seawater mesocosms differing in their nutrient status. Aquat Microb Ecol 19:255-267

Lochte K, Bjørnsen PK, Giesenhagen H, Weber A (1997) Bacterial standing stock and production and their relation to phytoplankton in the Southern Ocean. Deep-Sea Res II 44:321-340

Ludwig W, Strunk O, Westram R, Richter L and others (2004) ARB: a software environment for sequence data. Nucleic Acids Res 32:1363-1371

> Manganelli M, Malfatti F, Samo TJ, Mitchell BG, Wang H, Azam F (2009) Major role of microbes in carbon fluxes during Austral winter in the Southern Drake Passage. PLoS ONE 4:e6941

Manz W, Aamnn R, Ludwig W, Wagner M, Schleifer KH (1992) Phylogenetic oligonucleotide probes for the major subclasses of Proteobacteria: problems and solution. Syst Appl Microbiol 15:593-600

Manz W, Amann R, Ludwig W, Vancanneyt M, Schleifer KH (1996) Application of a suite of 16S rRNA-specific oligonucleotide probes designed to investigate bacteria of the phylum cytophaga-flavobacter-bacteroides in the natural environment. Microbiology 142:1097-1106

- Massana R, Pedrós-Alió C, Casamayor EO, Gasol JM (2001) Changes in marine bacterioplankton phylogenetic composition during incubations designed to measure biogeochemically significant parameters. Limnol Oceanogr 46: 1181-1188

> Murray AE, Preston CM, Massana R, Taylor LT, Blakis A, Wu K, DeLong EF (1998) Seasonal and spatial variability of bacterial and archaeal assemblages in the coastal waters off Anvers Island, Antarctica. Appl Environ Microbiol 64:2585-2595

> Murray AE, Arnosti C, De La Rocha CL, Grossart HP, Passow U (2007) Microbial dynamics in autotrophic and heterotrophic seawater mesocosms. II. Bacterioplankton community structure and hydrolytic enzyme activities. Aquat Microb Ecol 49:123-141

> Muyzer G, De Waal EC, Uitterlinden AG (1993) Profiling of complex microbial populations by denaturing gradient gel electrophoresis analysis of polymerase chain reaction-amplified genes coding for 16S rRNA. Appl Environ Microbiol 59:695-700

Muyzer G, Brinkhoff T, Nübel U, Santegoeds C, Schäfer H, Wawer C (1998) Denaturing gradient gel electrophoresis (DGGE) in microbial ecology. In: Akkermans ADL, van Elsas JD, Bruijn FJ (eds) Molecular microbial ecology manual. Kluwer Academic Publishers, p 1-23 
Neef A (1997) Anwendung der in-situ-Einzell-Identifizierung von Bakterien zur Populationsanalyse in komplexen mikrobiellen Biozönosen. PhD Thesis, Technische Universität München

Pinhassi J, Azam F, Hemphälä J, Long RA, Martinez J, Zweifel UL, Hagström $\AA$ (1999) Coupling between bacterioplankton species composition, population dynamics, and organic matter degradation. Aquat Microb Ecol 17:13-26

Porter K, Feig Y (1980) The use of DAPI for identification and enumeration of bacteria and blue-green algae. Limnol Oceanogr 25:943-948

Renaud SM, Thin LV, Parry DL (1999) The gross chemical composition and fatty acid composition of 18 species of tropical Australian microalgae for possible use in mariculture. Aquaculture 170:147-159

Riemann L, Steward GF, Azam F (2000) Dynamics of bacterial community composition and activity during a mesocosm diatom bloom. Appl Environ Microbiol 66:578-587

Rosenstock B, Simon M (2001) Sources and sinks of dissolved amino acids and proteins in a large and deep mesotrophic lake. Limnol Oceanogr 46:644-654

Rubin SI (2003) Carbon and nutrient cycling in the upper water column across the Polar Frontal Zone and Antarctic Circumpolar Current along $170^{\circ} \mathrm{W}$. Global Biogeochem Cycles 17, 1087, doi:10.1029/2002GB001900

Selje N, Simon M (2003) Composition and dynamics of particle-associated and free-living bacterial communities in the Weser estuary, Germany. Aquat Microb Ecol 30: 221-237

Selje N, Simon M, Brinkhoff T (2004) A newly discovered Roseobacter cluster in temperate and polar oceans. Nature 427:445-448

Editorial responsibility: Jed Fuhrman, Los Angeles, California, USA
Simon M, Azam F (1989) Protein content and protein synthesis rates of planktonic marine bacteria. Mar Ecol Prog Ser 51:201-213

> Simon M, Rosenstock B (2007) Different coupling of dissolved amino acid, protein, and carbohydrate turnover to heterotrophic picoplankton production in the Southern Ocean in austral summer and fall. Limnol Oceanogr 52: 85-95

Simon M, Glöckner FO, Amann R (1999) Different community structure and temperature optima of heterotrophic picoplankton in various regions of the Southern Ocean. Aquat Microb Ecol 18:275-284

Simon M, Rosenstock B, Zwisler W (2004) Coupling of epipelagic and mesopelagic heterotrophic picoplankton production to phytoplankton biomass in the Antarctic Polar Frontal Region. Limnol Oceanogr 49:1035-1043

> Straza TRA, Ducklow HW, Murray AE, Kirchman DL (2010) Abundance and single-cell activity of bacterial groups in Antarctic coastal waters. Limnol Oceanogr 55:2526-2536

West NJ, Obernosterer I, Zemb O, Lebaron P (2008) Major differences of bacterial diversity and activity inside and outside of a natural iron-fertilized phytoplankton bloom in the Southern Ocean. Environ Microbiol 10:738-756

> Zapata-Vélez AM, Trujillo-Roldán MA (2010) The lack of a nitrogen source and/or the $\mathrm{C} / \mathrm{N}$ ratio affects the molecular weight of alginate and its productivity in submerged cultures of Azotobacter vinelandii. Ann Microbiol 60: 661-668

Zhou J, Bruns MA, Tiedje JM (1996) DNA recovery from soils of diverse composition. Appl Environ Microbiol 62: 316-322

Submitted: March 5, 2012; Accepted: September 5, 2012 Proofs received from author(s): November 6, 2012 